\title{
Die mag van God volgens die belydenis van Daniël se vriende
}

\author{
J.L. Helberg \\ Dept. Ou en Nuwe Testament \\ Potchefstroomse Universiteit vir $\mathrm{CHO}$ \\ POTCHEFSTROOM
}

\begin{abstract}
A dehate regarding the control of God ower all events has lately been going on. This article attempts to indicate which light Daniel 3:17,18, in the context of the book as a whole, sheds on understanding the supreme mile of God by combining three factors: (jod's omnipotence, his freedom in exercising his ommipotence, and his personal way of exercising his powerfulness.
\end{abstract}

\section{Inleidend}

Die albestier van God het die afgelope tyd weer van verskillende kante onder die soeklig gekom. König (1992a:10) praat van God se "stryd en oorwinning" eerder as van sy beheer oor alles, hoewel hy nie God se heerskappy wil bevraagteken nie (1993:10), en volgens Nicol (1992a:10, 1992b:9) is God se beheer "nog op pad" om volle werklikheid te word (vgl. ook Van den Brink, 1992 oor Goddelike "Allmacht en omnipotence"; verder Miskotte, 1956:14-20, 45-47 oor die gedagte: as die gode swyg). Hierdie stellings is die vrug van 'n worsteling met die probleem van die kwaad in dic wêreld: die lyding, bedrog, onderdrukking, onreg, kindennishandeling en dergelike meer. As God in beheer is, dan is Hy mos in beheer van hierdie dinge. En hoe kan so iets met Hom en sy liefde gerym word? Gevolglik word weggeskram van die aanvaarding dat God alles bestier.

Die boek Daniël handel juis oor 'n situasie waarin dit lyk of nie God nie, maar onderdrukkende heidense magte op daardie tydstip in beheer van sake is. Die Siriese vors Antiogus Epifanes eis selfs goddelike eer vir homself op en is voorspoedig in alles wat hy teen die volhardende gelowiges doen (Dan. 8:12;11:36; vir hierdie byna algemene identifikasie, vgl. byvoorbeeld Burden, 1989: 965-967; Goldingay, 1989:9; Anderson, 1984:xiii). In hierdie artikel word aangedui hoe veral die getuienis van die drie vriende Sadrag, Mesag en Abednego (Dan. 3: $17,18)$ 'n belangrike perspektief bied op die problematiek van God se bestier van sake. Hierdie perspektief kom tot stand deur die verkondiging van God se mag as 
almag, vrymag en persoonlike mag (of persoonlike bestier) en verder hoe dit met die boek as geheel saamhang.

\section{Apokaliptiek: alles is tot in die fynste besonderhede bepaal}

Volgens (buite-Bybelse) apokaliptiese literatuur is God in beheer van sake; Hy het alles tot in die fynste besonderhede bepaal en alles verloop volgens daardie bepaalde Goddelike ordening. Juis hierdie sterk klem op die Goddelike beheer lewer egter probleme op, want die klem val op die Goddelike ordening van tydmatigheid en wetmatigheid waarvolgens alles verloop. God as die lewende God wat in die geskiedenis besig is, word na die agtergrond verplaas en juis dit veroorsaak onsekerheid en twyfel. Die geskiedenis word deïsties verstaan en die verloop van dinge vertoon ' $n$ deterministiese trek.

Die apokaliptiese geskrifte maak nie 'n geslote eenheid uit waarin almal dieselfde kenınerke vertoon nie. Vir ons doel hoef hier nie op die verskille ingegaan te word nie. Daar is sterk gemeenskaplike trekke ondanks die verskille (Russell, 1964:230-234; Collins, 1984:105,106; Nicholson, 1979). Volgens Lebram (1984:32-37) vertoon die wêreldbeskouing van die apokaliptiek die volgende kenmerke: die vrome is binne 'n historiese situasie geplaas waaruit hy hom nie kan onttrek nie en die bose bewys hom in die verloop van die wêreldgeskiedenis as 'n werklike, alles oorwinnende mag. Tog bestaan daar naas hierdie beperkte aardse wêreld 'n hemelse wêreld. Van die gelowige word vertrouensvolle onderwerping aan die wêreld- en lewensordeninge van die Allerhoogste God vereis, asook hoop op die uiteindelike oorwinning van die ryk van God en die erkenning van die verhewenheid van God. Die wêreld- en geskiedenisbeeld van die apokaliptiek is met ' $n$ bewuste logiese sistematiek opgebou. Vertwyfeling en sonde berus op nie-weet, en verlossing is kennis. Die verloop van die geskiedenis het 'n fisies-tegniese karakter. In die apokaliptiese tekening van die wêreldgeskiedenis kom God nie voor nie; die wêreldgeskiedenis verloop binne die raamwerk van die ordeninge wat God daarvoor gestel het. Die geskiedenis is daarom vir die leser nie 'n ontmoeting met God nie, maar 'n neutrale afloop van gebeurtenisse, 'n blote wagtyd. Hierdie grondtrekke van die apokaliptiese denke is nie iets spesifiek Joods of Bybels nie, maar behoort tot die denksfeer van alle Hellenistiese kulture. Die wêreldeinde is ' $n$ gebeurtenis wat deur die Godheid volgens bepaalde boaardse wetmatighede georden is, 'n gebeurtenis wat verwag moet word en deur openbaringe onthul kan word. Die apokaliptiek was 'n denkbeweging met aanhangers binne die uiteenlopendste groepe in Israel - ook binne die offisiële groepe.

Die boek Daniël het in sy huidige vorm binne hierdie klimaat tot stand gekom. Dit het gelyk asof alles bepaal is soos deur onpersoonlike natuurwette en asof die afloop van die geskiedenis soos die loop van 'n masjien is. Die gang van die ryke wat die verbondsvolk se lot bepaal, is onkeerbaar; die bedreiging en vervolging 
vir die verbondsvolk is onveranderlik; die momentum van die heidense magte is onstuitbaar en word erger en erger vanaf Nebukadnesar tot Antiogus Epifanes - ' $n$ vervolging wat op die vernietiging van die verbondsvolk sal uitloop $(8: 24,12: 7)$. Davies (1988:87) oordeel inderdaad dat God se "providence" in Daniël 10-12 bestaan uit voorkennis vanaf die begin en sy finale intrede, maar dat daar tussen hierdie twee uiterstes van die geskiedenis geen ruimte vir Goddelike optrede is nie. Hierdie artikel se bevinding is anders

\section{Die eenheid van die boek Daniël}

Die boek Daniël bestaan uit tien gedeeltes (met hfst. 10-12 as eenheid) wat elk op homself kan bestaan maar wat saam twee gedeeltes van wyd uiteenlopende aard vorn (hfst. 1-6 en 7-12, vgl. Collins, 1984:31). Die eerste deel is histories en die tweede apokalipties; tog vorn die boek 'n eenheid, soos bewys deur die feit dat die Aramese gedeelte (2:4b-7:28) hierdie twee afdelings oorvleuel (die res is Hebreeus). Verder blyk die eenheid van die boek uit die progressiewe parallelisme in hoofstuk 2, 7, 8, 9 en 11 (Baldwin, 1978:59-62). Die outeur van hoofstuk 7-12 het uitgebrei op die vroeëre visioen van Daniël en sodoende Daniël se profesieë in die lig van die kontemporère geskiedenis bevestig (Childs, 1979:616, 617). Die boek vorm ' $n$ geheel, al is dit nie 'n eenheid vanuit die perspektief van literêre geskiedenis nie, gesien die apokaliptiese aard van hoofstuk 7-12 teenoor die historiese inslag van hoofstuk 1-6 (Towner, 1984:6, Aalders, 1962:13-16). Verder vertoon die boek ook 'n eenheidstruktuur, soos aangetoon deur Goldingay $(1989: 4)$. Vergelyk byvoorbeeld sy voorstelling van die verskillende aspekte wat die verloop van die ballingskap tipeer:

Ballingskap en die vrae wat dit oproep: verhaal (1)

'n Visoen oor vier ryke (2)

'n Toets van getrouheid, en wonderlike redding (3)

'n Godspraak uitgelê en 'n koning gedaag en getug (4)

'n Godspraak uitgelê en 'n koning gedaag en afgesit (5)

'n Toets van getrouheid, en wonderlike redding (6)

'n Visoen oor vier ryke (7)

Aspekte van 'n visoen uitgebou (8)

Ballingskap en die vrae wat dit oproep: visioen (9)

Aspekte van hierdie visioen uitgebou (10-12)

Die verspringende reëls hierbo toon aan hoe gedeeltes in die tweede deel van die boek parallelle vorn met gedeeltes in die ecrste deel.

Burden (1987:206-208) sien Daniël 1-6 as 'n afwisseling van helde- en uitlegverhale, met 5 en 6 in omgekeerde volgorde; 7 het sterk ooreenkomste met 2 en vorm ' $n$ verbindingskakel tussen $1-6$ en 7-12 
Die historiese gedeelte (hfst. 1-6) en die apokaliptiese gedeelte (hfst. 7-11) van die boek Daniël moet aanvullend tot mekaar gelees word. Hoofstuk 1-6 reflekteer nie 'n gelyktydige 'teokratiese' beweging, met 'n 'eskatologiese' beweging wat beperk was tot Israel as geestelike entiteit nie (teenoor Plöger, 1965:30; Hanson, 1975:11, 12; vgl. Kratz, 1991:222-225, 284-286 oor die ineenstorting van eersgenoemde benadering in die tyd van Antiogus). Sowel Daniël as Qumran het 'n ooreenstemmende waardering vir die institusionele priesterskap en kultus (Davies, 1989:258). Hoofstuk 1-6 handel oor die situasie in die tyd van die verbondsvolk se Babiloniese ballingskap (en kort daarna). Die ballingskap was as 't ware die dood van die volk. Die terugkeer word daarom gesien as 'n opstanding uit die dood (Eseg. 37). Om hierdie rede word hierdie periode in die boek Daniël beskou as 'n periode wat 'n boodskap inhou vir die Jode in die soortgelyke tyd van Antiogus Epifanes, 'n paar eeue later. Die periode van Antiogus Epifanes lyk of die doodsuur vir die verbondsvolk aangebreek het, of die geskiedenis vir hulle gestol het en hulle lot as onderdrukte en selfs vervolgde volk onherroeplik is. Die dood het letterlik en figuurlik die lewe binnegedring.

Hoofstuk 1-6 dien as bemoediging vir die gelowiges in hulle geloofsvervolging en sê dat God 'n lewende en lewewekkende God is. Hy ruk 'n mens nie slegs voor die dood weg nie, maar red hom selfs binne die kake van die dood (binne 'n leeukuil en 'n brandende oond - Dan. 3,6). Hoofstuk 7-11 staan binne die geloofsvervolging en sê dat God nie altyd so red soos hierbo beskryf is nie, maar sy gelowiges soms as 'n prooi oorlaat aan die vervolging. Tog, so verkondig hierdie gedeelte, kan hulle volhard in hulle vertroue in God. Hy, die lewende en lewewekkende God, sal uiteindelik uitkoms bring vir die gelowiges wat bereid is om God bo alles te stel en die pad daarin enduit te loop. Sodanige gelowiges is hulle wat bereid is om die volle prys, die dood, te betaal. Vir hulle is daar 'n opstanding uit die dood (12:2). Dit is binne hierdie situasie wat Daniël 3:17-18 gelees moet word - ' $n$ gedeelte wat perspektief op die res van die boek werp en self ook vanuit die res van die boek in sy ware perspektief gesien kan word.

\section{Die aard en verkondiging van Daniël 3}

Die genrebepaling van die verhaal in Daniël 3 word verskillend gesien, byvoorbeeld as legende (Collins, 1984:55-57), heldeverhaal (Burden, 1987:208), en metafoor van Israel in ballingskap (Fewell, 1988:84; Lacocque, 1979:66). Vir ons doel is dit nie nodig om op die presiese genrebepaling in te gaan nie, maar is dit wesenlik dat die hoofstuk fokus op God wat red en dat die klem nie val op menslike vermoë en prestasie nie.

Die samestelling van Daniël 3 bevat die volgende hoofelemente (vgl. Collins, 1984-53-55; Burden, 1987:208): inleiding: dreiging en toetsing vir die gelowiges (v. 1-7), aanklag (v. 8-12), ondervaging en belydenis (v. 13-18), veroordeling (v. 19-23), wending ( v. 24-25), redding, insluitende die bevordering van en lofseg- 
ging aan God (v. 26-30). Die ondervaging deur die koning fokus op die religieuse kwessie wat op die spel is: wie is die God wat julle kan red?

Wat plasing betref, vertoon die hoofstuk trekke van die Neo-Babiloniese tydperk, maar ook van die Persiese (vgl die verwysings na die ampte in v. 2-3 en die klere in v. 21) en die Griekse tydperke (vgl. die musiekinstrumente soos die siter en die harp in v. 5). Dié gegewens pleit dus vir die Hellenistiese tyd, maar die hoofstuk is nie oorspronklik vir die tyd van Antiogus geskryf nie, want dit verwoord nie die destydse felle godsdienstige vyandskap teen die Jode nie (vgl. Collins, 1984: 58).

Wat die doel van hierdie hoofstuk betref: die vrees van Jode wat in diens van heidene was, word aangespreek en hulle word bemoedig. Die konflik is nie 'n toets van menslike voortreflikheid, soos gewoonlik by buite-Bybelse stof van hierdie aard die geval is nie, maar van Goddelike mag, asook van die gelowiges se getrouheid aan God. Hy is die God wat selfs op bonatuurlike maniere kan red, selfs heidense konings se gesindhede kan verander. Die Jode word bemoedig deur te wys dat godsdienstige trou nie alleen versoenbaar is met diens by' ' $n$ heidense koning nie, maar selfs tol verhoging kan lei. Verder wil dit die Jode daarop wys dat die gevare wat hulle bedreig, nie uiteindelik die oorhand het nie, maar dat God magtiger is as hulle teenstanders (Collins, 1984:58, 59). Ons kan verder wys op die hoofstuk se sterk herhaling van die opdrag van die koning en die uitvoering daarvan. Telkens word die amptenare en die musiekinstrumente en die "volke, nasies en taalgroepe' in besonderhede herhaal (v. 2, 3, 4, 5, 7, 10, 15). Daannee word uitdrukking gegee aan die koning se mag (Fewell, 1988:66) en die onveranderlikheid van die gebeurtenisse. Hierdie aspek word in hoofstuk 7-12 uit 'n ander hoek belig, naamlik in die verwysing na vasgestelde tye en gebeurtenisse. In vers 15 word daar dan 'n verbinding gemaak met God se mag in die vraag oor walter god sal kan red. Vers 22 en 23 benadruk die onveranderlikheid van die natuurlike werklikheid deurdat die persone wat vir Sadrag, Mesag en Abednego in die oond gooi, weens die geweldige hitte doodgebrand word. Terselfdertyd benadruk die verse die groter en andersoortige mag van God wat sy troue dienaars in hierdie selfde situasie bewaar. In die belydenis van die vriende word die refrein wat mag en onveranderlikheid benadruk, deurbreek, hulle getuig slegs oor die mag van God (Fewell, 1988:74) en bulle lojaliteit aan Hom.

\section{Die getuienis van Sadrag, Mesag en Abednego}

Daniël 3:17-18 lui:

Ons het ons God vir wie ons dien. Hy het die mag om ons te red uit die brandende oond, en Hy sal ons ook red uit u mag. Selfs as Hy dit nie doen nie, moet $u$ weet dat ons $u$ god nie sal dien nie, die goue beeld wat u laat oprig het. nie sal aanbid nie. 
Die eerste gedeelte kan ook soos volg vertaal word: 'As ons God vir wie ons dien, ons kan red, sal Hy ons red ...' (Porteous, 1962:47). Eksegete is byna eenstemmig daaroor dat die vriende nie die almag van God betwyfel nie - inteendeel (vgl. byvoorbeeld Anderson, 1984:34). Fewell (1988:75) meen ten onregte dat die vriende seker is oor God se gewilligheid om te red, maar onseker is of $\mathrm{Hy}$ in staat is om dit te doen. In verband met die woorde "ons God vir wie ons dien" merk Burden (1989:958) tereg op: "... dis nie eens nodig om sy naam te noem nie. Hy is 'n God van dade en nie van woorde nie". Jefferey (1956:401) skryf die verswyging van die naam ten onregte bloot toe aan die Jode se eerbied daarvoor. In aansiuiting by Keil sê Young (1949:91) dat die vriende bedoel: "ethical ability, i.e. the ability limited by the divine holiness and righteousness, not the impotence of God as such". Dus, "If, in his sovereign good pleasure, our God can deliver us, He will do so". Aalders $(1962: 79,80)$ vertaal duideliker: "Hetzij onze God ... in staat is ons te redden ... en Hij ons ... wil redden ...". Die teks se formulering is moeilik omdat dit twee dinge integreer. Enersyds sluit dit aan by die voorafgaande woorde van Nebukadnesar ("en watter god sal julle uit my mag kan red?"; vgl. ook Goldingay, 1989:16). Andersyds wil dit duidelik na vore bring dat dit in die ware godsdiens nie om blote onpersoonlike magsuitoefening gaan soos by die ongelowige aardse vorste nie, maar ook en veral om 'n vertrouensverhouding. Die toets gaan hier nie bloot om 'n momentele magstryd tussen God en Nebukadnesar met ' $n$ momentele afloop nie, maar ook om die volgehoue vertroue van God se gelowiges onder alle omstandighede. Die teks roep daarom die magsugtige vorste op tot selfondersoek en bemoedig tegelykertyd die gelowiges om te volhard.

Sadrag, Mesag en Abednego se woorde getuig van hulle geloof in die almag van God: Hy het die mag om hulle te red en Hy sal dit ook doen: God is die Albestierder, Hy is in belieer van alles. Hierdie geloof word bevestig deur die verloop van sake, naamlik dat 'n engel hulle as 't ware binne in die dood beskerm en God Hom so betoon as maghebber selfs oor die dood. (Hoofstuk 12:2 gaan nog verder op hierdie selfde pad en praat van opstanding; vgl. onder.) Hierdie siening vorm 'n skrille kontras met die mag van Nebukadnesar wat nie eens die mense wat sy wil uitvoer (v. 22) se lewe kan red nie. Hierdie vriende se belydenis gaan ook nog ' $n$ groot stap verder; dit bely nie net God se almag nie, maar ook sy vrymag. Hulle laat aan God die vryheid om inderdaad God te wees (vgl. ook Preuss, 1992:304) en volgens sy vrymagtige wil op te tree: "Selfs as Hy dit nie doen nie, moet $u$ weet dat ons u god nie sal dien nie ... ". Hulle geloof en vertroue verplig God nie om hulle te red nie en is nie ' $n$ middel om op 'n meganiese manier sy krag ten gunste van hulle aangewend te kry nie. Ware geloof en vertroue gaan gepaard met onvoorwaardelike oorgawe aan God se wil en maak dat 'n mens nie eudaemonisties ingestel is nie. Dit is dan ook oor hierdie vertroue wat Nebukadnesar hulle prys (v. 28). Die Goddelike wil kan anders wees as dit waarvoor die gelowige in sy geloofsvertroue bid en kan vir hom, menslik gesproke, nadelig wees. So was dit inderdaad vir die gelowiges in Antiogus Epifanes se tyd. Plöger (1965:65) wys daarop dat die koning in sy ongebonde mag gebind is aan 
sy gebod en die onderdane se houding daarteenoor. Die God wat deur die vriende vereer word, is egter waarlik ongebonde. Hy kan sy gehoorsame dienaars red. As Hy dit doen, is dit genade - genade wat steeds in die liefde gegrond is. As Hy dit nie doen nie, boet Hy nóg sy soewereine mag nóg die vertroue van sy dienaars in, want hulle het Hom lief ( $\mathrm{vgl}$. ook v. 28). In verband met die woorde "Selfs as Hy dit nie doen nie" sê Russell $(1989: 46,47)$ tereg:

It is not the 'if not' of doubt: it is the 'if not' of supreme faith in a God who, despite all appearances to the contrary, 'is able for all times to save those who draw near to ... him' (Heb. 7:25). 'Blessed are those who have not seen and yet believe' (John 20:29) ... This story ... does not present trust in God as some kind of insurance policy against suffering or pain or death ....

'n Deterninistiese benadering waarin daar nie 'n ontmoeting met God self in die geskiedenis is nie, maar slegs met die afloop van die geskiedenis volgens God se onveranderlike ordeninge (vgl. Lebram [1984:32-37] hierbo), is hier uitgesluit. Hier word gepraat van ons God. Hierdie uitdrukking het nie slegs 'n neutrale betekenis, een wat op 'n neutrale manier onderskeid maak tussen hulle God en die god van Nebukadnesar nie. Ons ( $o d$ druk 'n noue persoonlike verbintenis met God uit en verklank iets van die verbondsverhouding tussen God en sy volk, soos elders uitgedruk in die verbondsterminologie: "Ek sal julle God wees en julle sal my volk wees" (Jer. 31:33; Hos. 2:22). Die grond vir die vriende se standvastigheid is hulle verbinding met God, hierdie verbinding met Hom is vir hulle meer werd as die lewe. Hulle word nie basies gemotiveer deur die geloof in redding van die dood nie, ook nie basies deur geloof in 'n opstanding nie, nie deur iets wat hulle sal kry nie, maar deur iets wat hulle het, Iconand wat hulle het. Die diepste motivering vir hulle geloof en standvastigheid is teosentries, nie eudaemonisties of soteriologies nie, ook nie deterministies, geloof in 'n blote onveranderlike ordening van God nie, maar geloof en verbintenis met die lewende God. Daarom is die moontlikheid van hoop op opstanding hier nie uitgesluit nie (Porteous, 1962:47), maar dit staan heeltenal in die skadu van die verbinding aan God self. Eichrodt (1961:361) wys daarop dat selfs in 12:2 die belangstelling geheel en al gerig is op die volle herintrede in 'n lewe van gemeenskap met God.

Hierdie teosentriese benadering beheers die hele boek Daniël. Dieselfde geld van die Psalms. Die psalmdigters praat min oor ' $n$ toestand of redding na die dood, nie ondat hulle geen verwagting daaroor het nie (teenoor bv. Barth, 1947:164166 ), maar ondat hulle hulle lewe vind in hulle verbinding met God. Hulle is so op Hoin gerig dat hulle die res, soos die situasie na die dood, met vertroue aan Hom oorlaat. Christus neem ook hierdie teosentriese benadering as uitgangspunt om aan die Sadduseêrs te bewys dat daar in die Ou Testament ' $n$ opstanding geleer word. Hy knoop dit aan die uitdrukking "Ek is die God van Abraham, die God van Isak, en die God van Jakob". Hierdie teosentriese benadering en hierdie persoonlike verbinding met God, maak dat dit nie anders kan nie as dat Abraham, Isak en Jakob moet voortleef, want "Hy is nie 'n God van dooies nie maar van 
lewendes" (Matt. 22:32). Die vriende se getuienis getuig dus dat die drie aspekte, naamlik God se almag, vrymag en persoonlike bestier, geîntegreer is. Alleen so 'n benadering kan maak dat gelowiges onder alle omstandighede standvastig kan bly in die geloof in God, en wel as geloof in die lewende God en nie bloot in 'n bepalende krag nie (vgl. ook Kreuzer, 1983:297). Dit is dan ook wat die boek Daniel verkondig. God tree op 'n persoonlike manier op teen die skyn van die werklikheid in asof die geskiedenis die gang van 'n onverbiddelike afloop van onpersoonlike kragte is. Hierdie afloop van kragte impliseer dat die een wrede ryk die ander sal opvolg totdat die punt van totale vernietiging bereik word. Hieronder sal nou aangedui word hoe die genoemde drie aspekte in die res van die boek voorkom.

\section{God se almag in die boek Daniël}

Hierbo is daarop gewys dat die geskiedenis in die tyd van Antiogus Epifanes skynbaar gestol het en dit gelyk het of daar 'n meganiese afloop van 'n gedetermineerde geskiedenis was. Die boek Daniël beantwoord hierdie problematiek, nie deur die gedetermineerdheid van die gebeurtenisse te ontken nie, ook nie deur God se optrede bloot te sien as 'n oorwinning oor die bose magte nie (vgl. Gowan, 1986:54), maar deur determinering (bepaaldheid) tot sy uiterste grense te voer: God bestier alles as deel van sy doel. Dit word in elke hoofstuk verkondig, soos die volgende voorbeelde bewys:

* Nebukadnesar se beleëring van Jerusalem. In werklikheid is dit God wat die verbondsvolk oorgee in Nebukadnesar se mag (1:2) en wat sodoende hulle sonde deur Nebukadnesar se optrede straf $(9: 4-19)$.

* Die Babiloniese wyse manne se wysheid. God skenk die wysheid aan hulle en stel Daniël en sy vriende in staat om hulle wysheid tien maal te oortref $(1: 20)$.

* Nebukadnesar se imperiale mag. God laat toe dat hierdie mag tot sy toppunt groei, maar Hy teken dit as deel van 'n kwynende wêreldmag wat sal plek maak vir God se koninkryk (2:45).

* Nebukadnesar se verwaande optrede. God konfronteer Nebukadnesar met die mislukking van sy eie bestaan as ' $n$ menslike regeerder wat bokant die diere verhewe moet wees (4).

* Belsasar se ontheiliging van die heilige bekers uit die tempel van Jerusalem. God gebruik die Medies-Persiese ryk as middel om hierdie optrede te straf en die Galdeërs te verslaan (5).

* Die doodstraf (leeukuil) wanneer God in plaas van die koning aanbid word. God laat hierdie maatreël toe en bewaar die gelowige Daniël as ' $t$ ware in die dood (6). (Dieselfde geld van die weiering om Nebukadnesar se beeld te aanbid: Sadrag, Mesag en Abednego se oorlewing in die brandende oond, 
3.) God is inderdaad die lewende en lewewekkende God wat in staat is om sy dienaars te red (6:21-24).

* Antiogus Epifanes se poging on God te vervang met sy eie god en selfs om self god te word $(7: 25-27 ; 8: 10-12,23-25)$. God gee die mag aan "iemand soos 'n menslike wese", dic tweede Adam, wie se heerskappy 'n ewige heerskappy sal wees $(7: 13-18,27)$.

* Die geloofsvervolger se optrede om die gelowiges om die lewe te bring. God laat hulle uiteindelik uit die dood uit opstaan (12:2).

\section{God se vrymag in die boek Daniël}

Reeds die bock se begin benadruk die vrymag van God deur te sê dat dit Hy is wat die koning van Juda en ook 'n gedeelte van die tempelgereedskap in Nebukadnesar se mag oorgegee het $(1: 2)$. Dit was teen die algemene verwagting van die volk dat so iets met die verbondsvolk kan gebeur, wat staan nog dat die Here so iets sou doen. Met hierdie gebeurtenis wys God dat Hy nie gebonde is nie; selfs nie deur die verbondsverhouding nie (vgl. ook die latere bespreking van Daniël se gebed).

Nie omdat Daniël meer wysheid as ander mense het, maak hy aan Nebukadnesar sy droom bekend nie, maar ondat God dit juis deur Daniël wil doen en juis aan Nebukadnesar 'n openbaring omtrent die gang en einde van die aardse ryke wil gee $(2: 30,37-45)$. God is "Hy wat tye en omstandighede verander ... en wat ondeurgrondelike en verborge dinge openbaar" $(2: 21,22)$.

Nebukadnesar verklaar dat alle volke moet weet "dat die Allerhoogste mag het oor al die koninkryke op aarde en dat Hy dit gee aan wie Hy wil; Hy stel selfs die onbelangrikste mens daaroor aan" (4:17). Dieselfde stelling word in vers 25 en 31 herhaal, en vers 35 benadruk die gedagte nog verder: "Hy doen soos Hy besluit met die hemelse magte en met die mense op die aarde. Daar is niemand wat Hom daarvan kan weerhou en vir Hom kan sê: 'Wat doen U' nie."

In sy vryınag maak God minder direkte bemoeienis met koning Belsasar om hom tot inkeer en erkenning van God se heerskappy te bring en word hy nie eers deur Daniël tot bekering opgeroep soos Nebukadnesar nie $(5: 21-30 ; 4: 27)$. In sy vrymag gee God sy eie volk aan die mag van wêreldryke oor (1:2), maar Hy eis van laasgenoendes rekenskap van hulle optrede teenoor sy volk en sy tempelgereedskap (5:23).

Hoofstuk 6 spot as 't ware met die menslike mag en magsug. Koning Darius draai in sy eie onherroeplike wet vas en is magteloos om Daniël te red (6:9-17).

Alleen God het die insig, wysheid, mag en vryheid om onveranderlike gebeurtenisse en tye te bepaal sonder dat Hy daarin vasdraai of in sy optrede lamgelê word (vgl. 7:22: "die tyd het aangebreek"; 7.25: "vir die hele vasgestelde tyd", 8: 
14: "Twee duisend drie honderd aande en oggende ..."). Die feit dat daar 'n maghebber is wat allerhande verwaande dinge teen Hom kwytraak en sy verbondsvolk oorweldig $(7: 8,20,21,25 ; 8: 10-12,24,25)$ en voorspoedig is in alles wat hy aanpak $(8: 12,24)$, bind Hom nie in nie en maak Hom nie haastig nie. Op sy tyd $(7: 22)$ roep Hy tot verantwoording en gee Hy die heerskappy aan sy gelowiges $(7: 22,27)$.

Dat sy vasgestelde tye en gebeurtenisse Hom nie deterministies bind nie, maar sy vrymag onaangetas laat, blyk uit die formuleringe wat impliseer dat God, menslikerwys gesproke, tye verkort sowel as verleng ( $\mathrm{vgl}$. ook $2: 21,22)$. Die vasgestelde tye waarvan in hierdie tekste en in 9:25-27 en 11 en 12 gepraat word, beklemtoon dat God in volle beheer van elke gebeurtenis en elke oomblik is: niks sal korter of langer duur as wat Hy bepaal nie. 'n Mens kan dus in vervolging volhardend op Hom vertrou. God verkort die tyd (vgl. die "halwe tyd" van "'n Tyd, tye en 'n halwe tyd" = "die hele vasgestelde tyd", 7:25) sodat die vervolger nie in sy doel slaag nie al is hy "voorspoedig in alles wat hy aanpak", en sodat sy gelowiges nie bo hulle mate beproef word nie. God verleng ook die vasgestelde tyd (die sewentig jaar van verdrukking waarvan die profeet Jeremia gepraat het, sal sewentig vasgestelde tydperke wees, 9:2, 24). In hierdie tyd sal daar versoening met God bewerk word (9:24). Hier is dus nie sprake van 'n meganiese gedetermineerdheid van tye en gebeurtenisse nie, maar van God se volle beheer en bestier sowel as van sy vrymag.

Daniël smeek God om uitkoms vir sy volk op grond van God se vrymag om anders op te tree as wat die volk wat in sy sonde volhard, verdien: "nie omdat ons regverdig is nie, maar op grond van u groot barmhartigheid" (vgl. 9:4-19, veral 18)

In sy vrymag gebruik God die vervolging van sy volk om hulle te louter, te suiwer en te reinig (11:35). Hy laat die vernietiging van sy volk enduit loop en bring dan redding, al vra dit opstanding uit die dood $(12: 2,7,13)$.

\section{God se persoonlike bestier in die boek Daniël}

Dat sake volgens die boek Daniël nie verloop volgens 'n meganiese gedetermineerdheid nie, blyk verder daaruit dat die optrede van God sowel as die lot van mense religieus-eties gemotiveer word (vgl. ook Hartman \& Di Lella, 1978:107), soos hieronder aangetoon sal word. Die verbondsverhouding tussen God en sy volk speel hierin 'n belangrike rol.

Die rede waarom Daniël en sy vriende se omstandighede aan die hof van Nebukadnesar verander het, is dat Daniël "hom voorgeneem het om hom nie met die koning se kos en wyn te verontreinig nie" en daarvolgens opgetree het $(1: 8,17)$. Sowel menslike vryheid en verantwoordelikheid (verbondsverantwoordelikheid) 
as God se albestier word hier en in die res van die boek benadruk. Die mens het ook as enkeling vir God besondere waarde (Kreuzer, 1983:297, 369).

Die belangrike posisie van Daniël se vriende word bepaal deur sy versoek aan die koning en deur die getrone wyse waarop hulle aan die eise van die situasie voldoen het $(2: 49 ; 3)$. Nóg Daniël nóg die vriende word veronderstel om passief te wees en in wêreldontvlugting te leef. Nie alleen is die hele boek 'n oproep tot volharding in die geloof nie, maar ook 'n oproep dat die gelowiges hulle plek oral moet volstaan. Daniël bly onder die moeilikste omstandighede op sy pos in die openbare lewe en beklee selfs een van die hoogste regeringsposte, en dit te midde van die kom en gaan van die magtige regeerders $(2: 48,6: 27)$.

Nebukadnesar word opgeroep tot bekering en sy lot word bepaal volgens sy reaksie hierop $(4: 27,34,36)$. Koning Belsasar word gestraf omdat hy verwaand was hoewel hy geweet het wat met Nebukadnesar gebeur het en hom tog nie verootmoedig het nie $(5: 21,22)$. Koning Darius loof God as die lewende God, wat red en bevry, soos Hy met Daniël gedoen het $(6: 26,27)$.

Antiogus Epifanes word venictig oor sy aanmatiging teenoor God $(7: 25 ; 8: 11$, 25). Met hom bereik die dierliklieid van die wêreldryke (wat daarom as diere voorgestel word) sy hoogtepunt. Hy is slegs na die uiterlike menslik, slegs menslik op grond van die feit dat hy mensoë gehad het en 'n mond (maar wat allerlei verwaande dinge kwytgeraak het, 7:8, 20, 25). Hy was in werklikheid die teenoorgestelde van wat 'n ware mens is, naamlik 'n regeerder onder heerskappy van God. God sal 'n ware menslike regeerder voorsien, "iemand soos 'n menslike wese" $(7: 13,14)$.

Daniël se gebed in hoofstuk 9 bely met groot nadruk die verbondsvolk se sonde as rede vir hulle ellendige situasie (9:4-19). Selfs die ontsettende geloofsvervolging word dus nie deur Daniël gesien as iets waarvan die verbondsvolk 'n blote onskuldige slagoffer is nie

Die morele en religieuse grond vir God se toom $(8: 19,11: 36)$ blyk duidelik uit die verbinding daarvan met sonde $(9: 16)$, soos ook in positiewe sin gellmpliseer in die woorde oor dié wat gered sal word: "almal ... wat in die boek opgeskryf is" (12:2), hulle wat volhard on God te dien (11:33). Die gelowiges is nie blote slagoffers van martelaarskap nie, maar hulle ondergaan die martelaarskap deurdat hulle 'n bewuste en besliste keuse gemaak het deur nie te swig vir die vleiery van Antiogus nie (11:32). Die optrede van hemelse wesens het wel invloed op die gang van die gebeurtenisse op aarde, maar alles is onder God se persoonlike beheer. Hy is die Allerhoogste God $(7: 22,25)$, die God wat hierdie aardse werklikheid transendeer sonder om hier afwesig te wees. Hy oorbrug die aardse en hemelse sfere veral met sy engele (soos in die brandende oond en die optrede van die engele Gabriël en Migael, 9:21;12:1). Hy sal dit op 'n besondere wyse doen deur "iemand soos 'n menslike wese" aan wie die koninkryk gegee sal word en 
wat nou verbind is met die heiliges van die Allerhoogste, die ware Israeliete (7:13, 18; vgl. Gese, 1991:210; Anderson, 1984:87; Baldwin, 1978:142, 143; Lacocque, 1988:95, 147, 148). Die Allerhoogste God is "die lewende God", die God wat aktief is in gebeurtenisse en die geskiedenis (6:27,29; vgl. Kreuzer, 1983:295).

\section{Die plek van sonde}

In die getuienis van Sadrag, Mesag en Abednego is daar nie direk sprake van sonde nie. In die grootste gedeelte van die boek speel die sonde van die verbondsvolk ook nie eksplisiet ' $n$ rol nie. Die boek handel trouens oor die vervolging wat oor die verbondsvolk gekom het weens sy geloof in God. Tog werp veral Daniël se gebed in hoofstuk 9 belangrike lig op hierdie aspek. Hier is ' $n$ aangrypende belydenis van die sonde van die verbondsvolk (9:4-19) en van hulle ongehoorsaamheid aan die gebooie $(9: 10,11)$, en 'n smeking om vergifnis en uitkoms uit die lyding. Hierdie belydenis wys dat daar meer as een hoek is van waaruit na sake gekyk moet word. Te oordeel aan die wêreldlike ryke se aandeel is hulle die skuldiges in verband met die verbondsvolk se leed - hierdie siening geld veral vir Antiogus Epifanes. Die verbondsvolk moet egter verder en dieper kyk as om net ander verantwoordelik te hou vir hulle ellende; hulle moet nie net bewus wees van die korruptheid van die wêreld nie, maar ook van hulle eie korruptheid. Hulle staan altyd voor God as sondige mense wat skuldig is; nooit as mense aan wie God iets verskuldig is nie. Ook in geloofsvervolging het hulle geen grond om iets van God te eis of om Hom te verwyt nie. Dit is teen hierdie agtergrond wat die getuienis van Sadrag, Mesag en Abednego gesien moet word. Hulle is nie blote slagoffers van God se wil nie en hulle sien nie bloot uit na 'n beloning (soos 'n opstanding, 12:2) nie. Hulle voel hulleself totaal in God se diens, ook omdat hulle nie neutraal voor Hom staan nie, maar as versoendes; daarom het hulle ' $n$ volle vrede deur die ervaring van sy barmhartigheid, genade, liefde en trou (waarvan Danièl in sy gebed praat, $9: 4,9,18$ ).

\section{Samevatting}

In die getuienis van Sadrag, Mesag en Abednego in Daniel 3:17-18 is drie aspekte van God se albestier saamgevat. Hierdie aspekte, naamlik God se almag, vrymag en persoonlike bestuur is van grondliggende betekenis om die boek se verkondiging oor God se albestier te verstaan. God het alles bepaal, alle gebeurtenisse en alle tye, volgens sy eie goeddunke en Hy is lewend, persoonlik teenwoordig en in beheer van alles. Hy staan op so ' $n$ manier in ' $n$ verhouding met mense dat niks deterministies verloop nie, dat hulle nie maar net slagoffers van sy besluite is nie en dat indiwiduele mense vir Hom betekenis het.

God is almagtig en Hy gebruik selfs mense en ryke se negatiewe oogmerke en optrede om sy eie positiewe doel te dien. Hemel en aarde, lewe en dood, alles staan onder sy beheer en bestier. Hy is transendent en tegelyk aktief teenwoordig 
in hierdie wêreld. Hy is ook vrymagtig en is op geen manier gebonde nie, selfs nie om sy gelowiges wat volhard om Hom as die Almagtige God te bely en te dien, van die marteldood te bevry as hulle bid nie. Sy gelowiges kan wel daarvan seker wees dat Hy persoonlik in volle beheer van elke gebeurtenis en elke moment is. Daar is 'n skynbaar onherroeplike gang van gebeurtenisse soos deur wêreldheersers bepaal. Daar is inderdaad vasgestelde tye en gebeurtenisse, soos deur God bepaal, maar God verdwyn nie prakties op die agtergrond totdat hierdie gebeurtenisse afgeloop het nie. Hy deurbreek die onherroeplikheid van tye en gebeurtenisse in belang van sy gelowiges en sy doel. Hy is die lewende God, wat persoonlik teenwoordig is. Selfs teenoor die ongelowiges staan Hy nie onbetrokke nie, maar roep hulle op tot bekering om Hom as die enigste, lewende en reddende God te erken

Sy almag, vrymag en sy persoonlike bestier bied tegelykertyd die grolid vis gitoof in Hom, totale, selfverloënende oorgawe aan sy wil en optrede en vertroue in sy weg met ' $n$ mens se lewe. Ware gelowiges sien nie slegs na Hom op vir reding uit doodsgevaar nie, maar dien Hom ter will van Homself onder alle omstandighede. Daniël 3 en die boek Daniël as geheel benader die probleem van die gelowiges se lyding deur en deur teosentries; tog gaan dit in Daniël nie on 'n abstrakte God nie, maar om die lewende, teenwoordige God, wat 'n persoonlike verbondsverhouding met sy gelowiges beoefen. Om by Hom veilig te voel, behels on met Hom versoen te wees oor 'n mens se sondes, ten volle aan Hom te behoort in lewe en dood en daarom nie vir die dood terug te skrik as 'n mens se geloof in Hom en jou belydenis van Hom dit vereis nie. 'n Mens hoef jou nie van die wêreld te onttrek nie, maar moet op elke lewensterrein op jou pos bly deur jou onvoorwaardelik in God se diens te stel. Hy kan 'n mens selfs te midde van geloofsvervolging voorspoedig maak en selfs 'n invloedryke posisie daar besorg, soos vir Daniël en sy vriende. Die mens as enkeling het by Hom waarde sowel as verantwoordelikheid. Of dit 'n mens gespaar bly om weens jou geloof in God in doodsbedreiging te kom; en of jy binne die kake van die dood behoue sal bly, soos Daniël en sy vriende in die leeukuil en die brandende oond; en of jy dwarsdeur die doodsdal moet gaan, soos die baie gelowiges wat doodgemaak is, dit behoort tot die misterie van God se wil en optrede. 'n Mens kan in elke situasie op God bly vertrou, want Hy sal jou selfs in die dood bewaar en jou uit die dood laat opstaan. Daar is 'n band met Hom wat nooit gebreek sal word nie: die band soos vasgelê in sy verbond en wat beoefen word in 'n mens se geloof in Hom - in Hom die almagtige, vrymagtige, lewende God.

\section{Bibliografie}

AALDERS, Th C 1962. Daniel Kok Kampen. (Commentaar op het Oude Testament) ANDERSON, R A 1984 Signs and Wonders A Commentary on the Book of Daniel Grand Rapids Eerdmans (International Theological Commentary)

BALDWIN, J G 1978 Daniel Leicester : Intervarsity Press (Tyndale Old Testament Commentaries ) 
BARTH, C. 1947. Die Errettung vom Tode in den individuellen Klagen und Dankliedern des Alten Testaments. Zollikon : Evangelischer Verlag

BURDEN, J.J. 1987. Die boek Daniel. (In Burden, J J. \& Prinsloo, W.S. reds Tweegesprek met God. Kaapstad : Tafelberg. Die Literatuur van die Ou Testament. p. 195-220)

BURDEN, J.J. 1989. Daniël (In Van Zyl, A H red. Verklarende Bybel Kaapstad Lux Verbi. p. 950-974.)

CHILDS, B S. 1979. Introduction to the Old Testament as Scripture London: SCM

COLLINS, J.J. 1984. Daniel : with an Introduction to Apocalyptic Literature. Grand Rapids : Eerdmans. (The Forms of Old Testament Literature.)

DAVIES, P R 1988. Daniel Sheffield : JSOT Press (Old Testament Guides.)

DAVIES, P.R. 1989 The Social World of the Apocalyptic Writings. (In Clements, R E. The World of Ancient Israel Cambridge : Cambridge University Press. p 251-271.)

EICHRODT, W 1961. Theologie des Alten Testaments Gottingen : Vandenhoeck \& Ruprecht.

FEWELL, D.N. 1988 Circle of Sovereignty: A Story of Stories in Daniel 1-6 Sheffield: Almond Press.

GESE, H 1991. Alttestamentlichen Studien. Tubingen : Mohr

GOLDINGAY, J.E. 1989. Daniel. Dallas : Word Publishing. (Word Publishing Themes)

GOWAN, D.E. 1986. Eschatology in the Old Testament. Philadelphia : Fortress

HANSON, P.D 1975. The Dawn of Apocalyptic. Philadelphia : Fortress

HARTMAN, L F \& DI LELLA, A.A. 1978 The Book of Daniel Garden City : Doubleday (The Anchor Bible)

JEFFEREY, A. 1956. The Book of Daniel. ( $n$ The Interpreter's Bible VI. New York Abingdon. p. 339-549.)

KÖNIG, A. 1992. Beheer, of stryd en oorwinning? Die Kerkbode, 150(17):10, Oktober

KÖNIG, A. 1993. God se heerskappy nie bevraagteken. Die Kerkbode, 151(4): 10, Febr. 5

KRATZ, R G. 1991. Translatio imperii: Untersuchungen zu den aramaischen Danielerzahlungen und ihren theologiegeschictlichen Umfeld Neukirchen-Vluyn : Neukirchener Verlag. (Wissenschaftliche Monographien zum Alten und Neuen Testament.)

KREUZER, S. 1983. Der lebendige Gott. Stuttgart : Kohlhammer

LACOCQUE, A. 1979. The Book of Daniel. London : SPCK

LACOCQUE, A 1988. Daniel in His Time Columbia : University of South Carolina Press

LEBRAM, J.-C 1984 Das Buch Daniel. Zürich : Theologischer Verlag. (Züricher Bibelkommentare )

MISKOTTE, KH 1956. Als de goden zwijgen Amsterdam : Holland.

NICOL, W. 1992a Is God albeskikker? Beeld: 10, Oktober 27

NICOL, W. 1992b. Bewerk God alle gebeure? Beeld:9, November 17

NICHOLSON, E.W. 1979. Apocalyptic (In Anderson, GW ed Tradition and Interpretation Oxford : Clarendon Press. p. 189-213.)

PLÖGER, O 1965 Das Buch Daniel. Gutersloh Gerd Mohn (Kommentar zum Alten Testament.)

PORTEOUS, MW 1962. Das Danielbuch. Gottingen : Vandenhoeck \& Ruprecht (Das Alte Testament Deutsch)

PREUSS, P.D. 1992. Theologie des Alten Testaments. II Stuttgart : Kohlhammer

RUSSELL, D.S. 1964. The Method and Message of Jewish Apocalyptic. London : SCM

RUSSELL, D.S 1989. Daniel: An Active Volcano. Edinburgh. The Saint Andrew Press

TOWNER, W.S 1984. Daniel. Atlanta : John Knox Press (Interpretation: A Bible Commentary for Teaching and Preaching.)

VAN DEN BRINK, G 1992 Almacht und Omnipotence Keryyma und Dogma, 38(4) 260-279

YOUNG, E J. 1949. The Prophecy of Daniel Grand Rapids : Eerdmans 